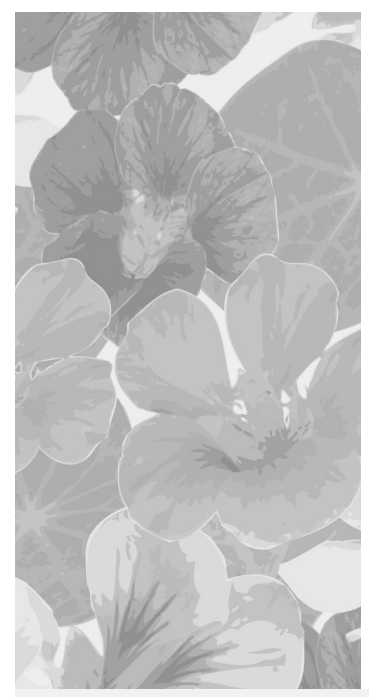

\title{
Które polskie czasopisma z zakresu medycyny estetycznej i kosmetologii spełniają kryteria czasopisma naukowego?
}

\section{Which Polish periodicals in aesthetic medicine and cosmetology meet the criteria of a scientific journal?}

\author{
Radosław Śpiewak, Agnieszka Zabiegała
}

Zakład Dermatologii Doświadczalnej i Kosmetologii, Wydział Farmaceutyczny Uniwersytet Jagielloński Collegium Medicum, Kraków

Estetol Med Kosmetol 2011; 1(1): 7-15

DOI: http://dx.doi.org/10.14320/EMK.2011.002

\section{Streszczenie}

Jednym z fundamentalnych warunków rozwoju medycyny estetycznej i kosmetologii jako petnoprawnych dyscyplin naukowych w ramach nauki polskiej jest możliwość ogłaszania oryginalnych wyników własnych badań w formie publikacji w czasopismach naukowych. Cel: Zbadanie, które z polskich czasopism poświęconych medycynie estetycznej lub kosmetologii spełniają kryteria czasopisma naukowego. Materiat i metody: Polskie czasopisma z dziedziny medycyny estetycznej lub kosmetologii zidentyfikowaliśmy na postawie kwerendy w katalogu Biblioteki Narodowej. Czasopisma, w których tytutach występowały ciągi znaków „estet” i „kosmet” oraz "cosmet”, „esthet” $\mathrm{i}$ „,aesthet” poddaliśmy analizie pod kątem obecności cech charakterystycznych dla czasopism naukowych, m. in. możliwości publikowania oryginalnych prac badawczych przez niezależnych autorów, recenzowania zgłoszonych prac, obecności rady naukowej złożonej z posiadających stopnie naukowe ekspertów gwarantujących merytoryczną jakość publikacji, a także indeksowania tych czasopism we wtórnych źródłach informacji naukowej (Medline/PubMed, EMBASE, Scopus, ISI Web of Knowledge, Google Scholar, Polska Bibliografia Lekarska). Wyniki: Zidentyfikowaliśmy 23 aktualnie wydawane polskojęzyczne czasopisma poświęcone tematyce medycyny estetycznej lub kosmetologii, spośród których minimalne kryteria czasopisma naukowego spetniały cztery tytuty: Academy of Aesthetic and AntiAging Medicine, Dermatologia Estetyczna, Dermatologia i Kosmetologia Praktyczna oraz Polish Journal of Cosmetology. Wnioski: Obecność polskojęzycznych czasopism naukowych publikujących oryginalne prace badawcze z zakresu medycyny estetycznej i kosmetologii stwarza podstawę rozwoju tych dyscyplin w ramach nauki polskiej. Czynnikiem ograniczającym rozwójjest mała dostępność tych czasopism oraz brak czasopisma interdyscyplinarnego, umożliwiającego swobodną komunikację pomiędzy przedstawicielami różnych zawodów. Jako środek zaradczy, proponujemy powołanie nowego czasopisma Estetologia Medyczna i Kosmetologia-czasopisma typu Open Access dedykowanego nieograniczonej i szybkiej interdyscyplinarnej komunikacji naukowej między polskimi badaczami aktywnymi w tej dziedzinie.

Stowa kluczowe: medycyna estetyczna, kosmetologia, czasopisma naukowe, bibliografia, bibliometria

\begin{abstract}
Among fundamental prerequisites for the development of aesthetic medicine and cosmetology as rightful disciplines within Polish science is the possibility of communicating original research results in scientific journal. Aim: To study which Polish periodicals devoted to the topics of aesthetic medicine or cosmetology fulfil criteria of a scientific journal. Material and methods: Polish periodicals devoted to aesthetic medicine or cosmetology were identified by means of a query submitted to the National Library catalogue that indexes all Polish publications. Periodicals whose titles contained stems "estet" or "kosmet" (Polish spelling), "cosmet", "esthet" or "aesthet" were analysed for the presence of features characteristic of scientific journals, including the possibility of publishing original research articles by independent authors, peer-reviewing of submitted articles, presence of a board of experts with academic grades who warrant the scientific quality, and indexing in secondary sources of scientific information (Medline/PubMed, EMBASE, Scopus, ISI Web of Knowledge, Google Scholar, Polish Medical Bibliography). Results: We have identified 23 active Polish periodicals with the topic of aesthetic medicine or cosmetology. Of these, only four have fulfilled the criteria of a scientific journal: Academy of Aesthetic and Anti-Aging Medicine, Dermatologia Estetyczna (Aesthetic Dermatology), Dermatologia i Kosmetologia Praktyczna (Practical Dermatology and Cosmetology) and Polish Journal of Cosmetology. Conclusions: The existence of Polish-language scientific journals devoted to aesthetic medicine and cosmetology enables the development of these disciplines within Polish science. However, the access to the content of these journals is limited, and there is a lack of an interdisciplinary journal allowing for unrestricted communication between representatives of various professions active in aesthetic medicine and cosmetology. To remove this impediment, we propose a new Open Access journal Estetologia Medyczna i Kosmetologia (Medical Aesthetology and Cosmetology) as a platform for unrestricted and rapid interdisciplinary scientific communication between Polish researchers active in this area.
\end{abstract}

Key words: aesthetic medicine, cosmetology, scientific journals, bibliography, bibliometrics

Copyright @ 2011 the Authors (text) and Radostaw Śpiewak (layout \& journal compilation). All rights reserved. 


\section{Bez publikacji nauka jest martwa}

Gerard Piel (1915-2004)

Prowadzenie badań naukowych jest podstawą rozwoju każdej dziedziny naukowej. Bez nowych odkryć nauka ulega stagnacji i zamiera. Dlatego, aby zapewnić dopływ nowych wyników do nauki, awans pracowników akademickich zależy w znacznej mierze od ich wkładu w tym zakresie. Stopnie naukowe doktora i doktora habilitowanego można uzyskać wyłącznie na podstawie oryginalnych prac badawczych. Na większości uczelni warunkiem wszczęcia przewodu doktorskiego jest wylegitymowanie się kandydata określoną liczbą (zwykle od 1 do 3) opublikowanych oryginalnych artykułów badawczych. Warunkiem przeprowadzenia przewodu habilitacyjnego jest przedstawienie przez kandydata spójnego cyklu własnych, poświęconych jednemu zagadnieniu naukowemu publikacji oryginalnych, w których planowaniu i wykonaniu kandydat odegrał wiodącą rolę. Jak z tego wynika, artykuły oryginalne stanowią podstawę nie tylko rozwoju danej dziedziny naukowej, lecz także awansu pracujących w niej naukowców. W celu zapewnienia wszystkim zainteresowanym możliwości skorzystania z wyników badań w danej dziedzinie, obowiązującą formą rozliczania naukowców z efektów ich pracy jest publikowanie artykułów przedstawiających wyniki własnych badań w czasopismach naukowych, których wartość merytoryczna gwarantowana jest przez rady naukowe złożone $\mathrm{z}$ autorytetów w danej dziedzinie, a także niezależnych ekspertów-recenzentów.

Termin „artykuł oryginalny” (a ściślej „oryginalny artykuł badawczy”) oznacza artykuł przedstawiający po raz pierwszy wyniki określonych badań. Przymiotnik ,oryginalny” ma tu zatem nie tylko potoczne znaczenie „różniący się od innych” (,nie będący plagiatem"), lecz dodatkowo implikuje, że dany artykuł zawiera pierwszy opis przeprowadzonych przez autorów badań naukowych wraz z ich wynikami. Opis sposobu wykonania badań i wyników jest sformalizowany, co daje możliwość powtórnej analizy opublikowanych wyników, oceny trafności przyjętych założeń i metod, ewentualnej weryfikacji (w tym powtórzenia opisanych eksperymentów), a także twórczego rozwinięcia przez innych badaczy. Najważniejsze formalne cechy oryginalnego artykułu badawczego przedstawia tabela 1. Niezależnie od poprawności formalnej i wartości merytorycznej, tekst może zostać uznany za artykuł naukowy wyłącznie w przypadku opublikowania w czasopiśmie naukowym. Nawet najbardziej odkrywczy i przełomowy artykuł badawczy nie zostanie uznany za publikację naukową, jeśli ukaże się $\mathrm{w}$ prasie codziennej, biuletynie internetowym lub magazynie branżowym. Typowe cechy czasopisma naukowego zostały przedstawione $\mathrm{w}$ tabeli 2. Jednym z najważniejszych warunków uznania czasopisma za naukowe jest regularne publikowanie w nim oryginalnych artykułów badawczych. Dobre prace przeglądowe są cennym dopełnieniem prac oryginalnych - ich wartość polega na systematyzowaniu wyników i wniosków z wielu badań, co ułatwia czytelnikowi szybką orientację w danym zagadnieniu. Młodym adeptom nauki pisanie pracy przeglądowej pod opieką doświadczonego naukowca daje okazję do systematycznego zagłębienia się w określone zagadnienie. Doświadczonym badaczom daje możliwość podsumowania życiowego dorobku, podzielenia się z czytelnikami zgromadzoną wiedzą, doświadczeniem i przemyśleniami. Oryginalne artykuły badawcze zajmują jednak w literaturze naukowej znacznie wyższą pozycję od prac przeglądowych. Wydaje się dość oczywiste, że rozwój dziedziny naukowej opartej wyłącznie na oryginalnych pracach badawczych nie byłby zagrożony, choć zapewne byłby mniej przystępny dla młodych adeptów nauki, natomiast dziedzinę opartą wyłącznie na pracach przeglądowych bez dopływu nowych wyników badawczych czekałaby nieuchronna wtórność i degeneracja. Dlatego, mimo niewątpliwego pożytku z dobrych publikacji wtórnych, które porządkują i systematyzują wyniki badań oryginalnych innych naukowców, nie ma możliwości zbudowania kariery akademickiej wyłącznie na pracach przeglądowych.

Tabela 1. Najważniejsze cechy oryginalnego naukowego artykutu badawczego

Przedstawia wyniki zaplanowanych i systematycznie przeprowadzonych badań (eksperymenty, obserwacje).

- Stanowi pierwsze ogłoszenie opisanych badań oraz ich wyników.

- Stanowi relację z pierwszej ręki (autorzy artykułu uczestniczyli w wykonaniu badań).

- Posiada sformalizowaną strukturę (podział na sekcje, stosowanie śródtytułów), a w szczególności:

posiada tytuł precyzyjnie określający treść artykułu, zawiera pełną identyfikację wszystkich autorów artykułów (nazwiska) wraz $\mathrm{z}$ afiliacją (nazwy instytucji, w których praca została wykonana) i adresem do korespondencji,

zawiera streszczenie (przynajmniej w jednym języku) przedstawiające w skrócie lecz precyzyjnie cele, metody, wyniki oraz wypływające z pracy wnioski,

zawiera słowa kluczowe,

zazwyczaj zawiera wstęp zarysowujący stan wiedzy przed podjęciem badania a także przesłanki do podjęcia opisywanych badań,

zawiera informację o celu przeprowadzonych badań, pytaniu badawczym lub roboczej hipotezie do zweryfikowania,

zawiera precyzyjny opis badanych obiektów, w tym kryteria włączenia lub odrzucenia poszczególnych obiektów z przeprowadzonych badań, 
zawiera opis zastosowanych metod badawczych (zbieranie danych, analiza statystyczna, itd.) na tyle ścisły, aby inni naukowcy $\mathrm{z}$ danej dziedziny byli w stanie na jego podstawie powtórzyć (zweryfikować) opisane badania,

- zawiera szczegółowy opis uzyskanych wyników (statystyka opisowa, analiza istotności statystycznej, analiza relacji między zmiennymi), a w szczególności tych, które w sposób bezpośredni odnoszą się do celu badań, odpowiadają na zadane pytanie badawcze lub testują hipotezę,

- zawiera dyskusję, w której wyniki pracy porównywane są do wyników innych badaczy, omawiane są potencjalne implikacje uzyskanych wyników, źródła możliwych błędów, itd.,

- zawiera wnioski, stanowiące podsumowanie i uogólnienie najważniejszych obserwacji poczynionych $\mathrm{w}$ trakcie pracy, które bezpośrednio odpowiadają na poszczególnym celom lub pytaniom badawczym podanym w pracy, albo przyjmują lub odrzucają hipotezę roboczą pracy,

- zawiera spis piśmiennictwa, czyli listę artykułów naukowych, z których badacze czerpali inspirację przy wyborze tematu i metodyki badań, lub których wyniki dyskutowali w kontekście swojej pracy,

- zawiera odwołania do piśmiennictwa zgodnie $\mathrm{z}$ zasadami obowiązującymi $\mathrm{w}$ publikacjach naukowych (zaznaczenie miejsc cytowania w tekście pracy, w wykazie piśmiennictwa pełne dane bibliograficzne źródeł obejmujące nazwiska autorów, tytuły artykułów i czasopism, roczniki, tomy, zeszyty, strony),

- zawiera deklarację autorów o źródłach finansowania opisanych badań, oraz o potencjalnym konflikcie interesów (np. czy autorzy badania określonego wyrobu otrzymują wynagrodzenie od producenta wyrobu badanego lub konkurencyjnego).

- Przed opublikowaniem podlega recenzji przez niezależnych ekspertów, którzy oceniają wartość i oryginalność publikacji i ewentualnie wskazują, jakie poprawki muszą być dokonane przed publikacją.

Tabela 2. Cechy charakterystyczne czasopism naukowych, które odróżniają je od czasopism branżowych i popularnych

- Opublikowana* informacja o tym, że wydawnictwo stanowi czasopismo naukowe.

- Opublikowana* informacja o zakresie tematycznym czasopisma.

- Opublikowana* informacja o radzie naukowej /programowej czasopisma składającej się z osób posiadających stopnie lub tytuł naukowy (doktor, doktor habilitowany, profesor) - ekspertów w danej dziedzinie, gwarantujących poziom merytoryczny publikowanych prac naukowych.

- Opublikowana* informacja, że artykuły naukowe składane do publikacji w czasopiśmie podlegają recenzji.

- Opublikowane* zalecenia dla autorów na temat sposobu przygotowania prac.
- Regularne zamieszczanie oryginalnych artykułów badawczych, dla których dane czasopismo jest pierwszym miejscem publikacji.

- Wyraźne określenie (w spisie treści lub na stronach tytułowych) charakteru poszczególnych artykułów z wyróżnieniem artykułów oryginalnych, artykułów przeglądowych, kazuistycznych, redakcyjnych, listów do redakcji, itd.

- Przestrzeganie formalnej struktury artykułu naukowego (patrz tabela 1).

- Indeksowanie czasopisma we wtórnych źródłach informacji naukowej (np. bazach bibliograficznych PubMed, EMBASE, Scopus, ISI Web of Knowledge, Google Scholar, Polska Bibliografia Lekarska lub innych o podobnym charakterze).

- Organizacja zawartości (podział czasopisma na tomy, ciągła numeracja stron w obrębie tomów).

*Informacje zamieszczone w samym czasopiśmie lub w innej powszechnie dostępnej formie, np. na stronie internetowej czasopisma

Zgodnie z definicją publikacji naukowej podaną przez (Council of Medical Editors) [1], istotnym warunkiem, który powinno spełniać czasopismo naukowe jest fakt indeksowania jego zawartości w tzw. wtórnym źródle informacji naukowej (bazy bibliograficzne, np. PubMed, Scopus, EMBASE, Google Scholar, Polska Bibliografia Lekarska lub podobne). Uzależnienie uznania danego czasopisma za naukowe od faktu indeksowania go w bazach bibliograficznych ma na celu zapewnienie dostępności publikowanych wyników badań dla innych badaczy. Żaden naukowiec, nawet gdyby poświęcił na to cały swój czas, nie jest w stanie czytać na bieżąco całego piśmiennictwa ukazującego się w swojej dziedzinie, nie jest zatem w stanie w taki sposób zidentyfikować artykułów istotnych z punktu widzenia własnych badań. W tej sytuacji jedynym praktycznym i efektywnym sposobem spełnienia wymogu dostępności publikacji naukowej dla wszystkich zainteresowanych jest indeksowanie publikacji naukowych w tzw. wtórnych źródłach informacji naukowej, czyli bazach bibliograficznych dających możliwość szybkiego wyszukania artykułów na określony temat. Najważniejsze z punktu widzenia medycyny estetycznej i kosmetologii wtórne źródła informacji naukowej (bazy bibliograficzne) to:

- PubMed - baza bibliograficzna wydawana przez Narodową Bibliotekę Medycyny USA obejmująca ponad 21 milionów artykułów naukowych, bezpłatnie dostępna przez Internet i uznawana jest za najbardziej popularne na świecie wtórne źródło informacji naukowej w zakresie nauk biomedycznych [2].

- EMBASE - baza bibliograficzna publikowana przez wydawnictwo Elsevier, zawierająca ponad 25 milionów rekordów, w tym wiele publikacji europejskich nie uwzględnionych przez PubMed. Początkowo baza ta była przeznaczona do gromadzenia publikacji naukowych przydatnych dla menedżerów ochrony zdrowia i urzędów rejestracji leków, 
obecnie obejmuje szeroki zakres nauk biomedycznych. Korzystanie z niej wymaga subskrypcji [3].

- Scopus - bibliograficzna baza danych uważana za źródło informacji bibliograficznej bardziej reprezentatywne dla czasopism europejskich od PubMed. Obok indeksowania artykułów naukowych, gromadzi również informację na temat ich cytowania $\mathrm{w}$ innych publikacjach. Korzystanie $\mathrm{z}$ tej bazy wymaga subskrypcji [4].

- Web of Knowledge (dawna „lista filadelfijska”, Web of Science) jest uważana za najbardziej prestiżową bazę informacji medycznej. Wskaźniki z tej bazy: omówiony w dyskusji Impact Factor oraz liczba cytowań są w wielu krajach (także w Polsce) podstawą oceny dorobku naukowców przy staraniach o awans akademicki, stopnie naukowe i tytuł profesora. Korzystanie z tej bazy wymaga subskrypcji [5].

- Google Scholar to wtórne źródło informacji naukowej dostarczane przez operatora popularnej wyszukiwarki internetowej Google. W jednym miejscu można wyszukiwać materiały z wielu dziedzin nauki i źródeł: artykuły recenzowane, prace naukowe, książki, streszczenia i artykuły pochodzące z wydawnictw naukowych, towarzystw naukowych, repozytoriów materiałów zgłoszonych do publikacji, uniwersytetów i innych organizacji akademickich. Wyszukiwarka Google Scholar sortuje publikacje nadając wagi tekstowi pracy, autorowi, oraz czasopismu naukowemu, a ponadto analizuje częstość cytowania danego artykułu w innej literaturze naukowej. Ta działająca jak wyszukiwarka internetowa baza jest dostępna bezpłatnie [6].

Każda z wyżej wymienionych wtórnych baz informacji naukowej ma swoje silne i słabe strony, a kwerendy przeprowadzone za pomocą różnych baz dają odmienne wyniki, dlatego przy wyszukiwaniu literatury naukowej nie można ograniczać się do poszukiwania w jednej bazie [7,8]. Za pomocą baz Web of Knowledge, Scopus oraz Google Scholar można ponadto sprawdzić, ile razy publikacje danego autora były cytowane przez innych naukowców, co również jest jednym kryteriów awansu akademickiego [9].

Jak wykazaliśmy powyżej, dla rozwoju każdej dziedziny naukowej niezbędne jest istnienie czasopism naukowych publikujących oryginalne artykuły badawcze. Zatem warunkiem rozwoju medycyny estetycznej oraz kosmetologii jest istnienie czasopism naukowych poświęconych tym dziedzinom. W literaturze międzynarodowej ukazuje się kilkanaście czasopism poświęconych tej tematyce i spełniających definicję czasopisma naukowego (tabela 3). Natomiast autorzy polscy pragnący publikować artykuły naukowe $\mathrm{z}$ zakresu medycyny estetycznej i kosmetologii w języku ojczystym natrafiają na istotne przeszkody, wśród których na pierwsze miejsce wysuwa się trudność zidentyfikowania czasopism naukowych wśród licznych polskojęzycznych periodyków poświęconych tej tematyce. Wybór niewłaściwego czasopisma do publikacji swoich badań może skutkować późniejszą odmową uznania danego artykułu jako części dorobku naukowego autora.

Tabela 3. Przegląd aktualnie ukazujących się międzynarodowych indeksowanych czasopism naukowych z dziedziny medycyny estetycznej i kosmetologii (stan: lipiec 2011)

\begin{tabular}{|c|c|c|c|c|c|c|}
\hline $\begin{array}{l}\text { Tytul } \\
\text { czasopisma }\end{array}$ & ISSN & PubMed & EMBASE & Scopus & WOK & $\begin{array}{l}\text { Google } \\
\text { Scholar }\end{array}$ \\
\hline $\begin{array}{l}\text { Aesthetic Plastic } \\
\text { Surgery }\end{array}$ & $\begin{array}{l}0364- \\
216 \mathrm{X}\end{array}$ & $1981 \rightarrow$ & $1976 \rightarrow$ & $1976 \rightarrow$ & $\mathrm{IF}=1,252$ & + \\
\hline $\begin{array}{l}\text { Aesthetic Surgery } \\
\text { Journal }\end{array}$ & $\begin{array}{l}1090- \\
820 \mathrm{X}\end{array}$ & $2008 \rightarrow$ & $2002 \rightarrow$ & $1995 \rightarrow$ & - & + \\
\hline $\begin{array}{l}\text { Annales de } \\
\text { Chirurgie Plastique } \\
\text { et Esthetique }\end{array}$ & $\begin{array}{l}0294- \\
1260\end{array}$ & $1983 \rightarrow$ & $1983 \rightarrow$ & $1983 \rightarrow$ & $\mathrm{IF}=0,521$ & + \\
\hline $\begin{array}{l}\text { Clinical Cosmetic } \\
\text { and Investigational } \\
\text { Dermatology }\end{array}$ & $\begin{array}{l}1178- \\
7015\end{array}$ & 2008 & - & $2009 \rightarrow$ & - & + \\
\hline $\begin{array}{l}\text { Cosmetic } \\
\text { Dermatology }\end{array}$ & $\begin{array}{l}1041- \\
3766\end{array}$ & - & 2002-2007 & $\begin{array}{l}2002- \\
2008\end{array}$ & - & + \\
\hline $\begin{array}{l}\text { Dermatologia } \\
\text { Cosmetica Medica } \\
\text { y Quirurgica }\end{array}$ & $\begin{array}{l}1665- \\
4390\end{array}$ & - & 2005-2006 & $2005 \rightarrow$ & - & - \\
\hline $\begin{array}{l}\text { International } \\
\text { Journal of Cosmetic } \\
\text { Science }\end{array}$ & $\begin{array}{l}0142- \\
5463\end{array}$ & $2008 \rightarrow$ & $1979 \rightarrow$ & $1979 \rightarrow$ & - & + \\
\hline $\begin{array}{l}\text { Journal of Applied } \\
\text { Cosmetology }\end{array}$ & $\begin{array}{l}0392- \\
8543\end{array}$ & - & $1985 \rightarrow$ & $1985 \rightarrow$ & - & + \\
\hline $\begin{array}{l}\text { Journal of Cosmetic } \\
\text { and Laser Therapy }\end{array}$ & $\begin{array}{l}1476- \\
4172\end{array}$ & $2001 \rightarrow$ & $\begin{array}{l}\text { 1999-2001, } \\
\text { 2005-2006 }\end{array}$ & $1990 \rightarrow$ & IF $=1,849$ & + \\
\hline $\begin{array}{l}\text { Journal of Cosmetic } \\
\text { Dermatology }\end{array}$ & $\begin{array}{l}1473- \\
2130\end{array}$ & $2006 \rightarrow$ & $2006 \rightarrow$ & $2002 \rightarrow$ & - & + \\
\hline $\begin{array}{l}\text { Journal of Cosmetic } \\
\text { Science }\end{array}$ & $\begin{array}{l}1525- \\
7886\end{array}$ & $2001 \rightarrow$ & - & $1996 \rightarrow$ & $\mathrm{IF}=0,215$ & + \\
\hline $\begin{array}{l}\text { Journal of Plastic } \\
\text { Reconstructive and } \\
\text { Aesthetic Surgery }\end{array}$ & $\begin{array}{l}1748- \\
6815\end{array}$ & $2006 \rightarrow$ & - & $2006 \rightarrow$ & $\mathrm{IF}=1,660$ & + \\
\hline $\begin{array}{l}\text { Kosmetische } \\
\text { Medizin }\end{array}$ & $\begin{array}{l}1430- \\
4031\end{array}$ & - & 2003-2007 & $2003 \rightarrow$ & - & + \\
\hline $\begin{array}{l}\text { WOK - Web of Kr } \\
\text { w danej bazie (sta } \\
\text { Citation Reports. I } \\
\text { wg Journal Citation }\end{array}$ & $\begin{array}{l}\text { edge, } \\
\text { a lip } \\
\text { Imp }\end{array}$ & $\begin{array}{l}\text { mbol, , } \\
\text { 2011). } \\
\text { Factor, }\end{array}$ & $\begin{array}{l}\text { nacza, że } \\
\text { a: PubMe } \\
\text { ołczynnik }\end{array}$ & $\begin{array}{l}\text { asopism } \\
E M B A \\
\text { olywu }\end{array}$ & $\begin{array}{l}\text { adal indek } \\
\text { Scopus, } \\
\text { sopisma z }\end{array}$ & $\begin{array}{l}\text { wane jest } \\
\text { Journal } \\
2010 \text { rok }\end{array}$ \\
\hline
\end{tabular}

\section{Cel}

Celem niniejszej pracy była analiza ukazujących się aktualnie w Polsce czasopism z dziedziny medycyny estetycznej i kosmetologii oraz ustalenie, które z nich spełniają kryteria czasopisma naukowego, dzięki czemu publikowanie w nich liczy się do dorobku naukowego i może być podstawą kariery akademickiej.

\section{Materiat i metody}

Czasopisma z dziedziny medycyny estetycznej i kosmetologii włączone do prezentowanej analizy zidentyfikowano na postawie kwerendy w internetowym katalogu Biblioteki Narodowej (BN) [11]. Narodowy Ośrodek ISSN Biblioteki Narodowej nadaje unikalny międzynarodowy znormalizowany numer 
wydawnictwa ciągłego ISSN (International Standard Serial Number) wszystkim czasopismom wydawanym na terenie Rzeczypospolitej Polskiej. Wydawcy są ustawowo zobowiązani do przesyłania do Ośrodka egzemplarzy każdego nowego numeru czasopisma, które są niezwłocznie wciągane do katalogów BN. Można zatem z dużym prawdopodobieństwem przyjąć, że katalogi $\mathrm{BN}$ obejmują wszystkie legalnie wydawane w Polsce czasopisma. W katalogu BN wyszukaliśmy czasopisma, w których tytułach występowały ciągi znaków „estet” i ,kosmet” oraz odpowiednio w języku angielskim „cosmet”, ,esthet” i ,aesthet”. Następnie z listy czasopism objętych prezentowaną analizą wykluczyliśmy tytuły wydawane za granicą oraz czasopisma, których wydania zaprzestano, tj. dla których w katalogu internetowym BN i bazie polskich bibliotek „Nukat” [12] nie odnotowano ani jednego numeru datowanego na 2010 lub 2011 rok (analizę przeprowadziliśmy między majem a lipcem 2011). W kolejnym etapie zidentyfikowane czasopisma poddaliśmy analizie pod kątem obecności wymienionych w tabeli 2 cech charakterystycznych dla czasopism naukowych, oraz sprawdziliśmy, czy czasopisma wykazujące takie cechy są indeksowane we wtórnych źródłach informacji naukowej. Oprócz omówionych wcześniej międzynarodowych baz bibliograficznych PubMed, EMBASE, Scopus, Web of Knowledge oraz Google Scholar uwzględniliśmy również Polską Bibliografię Lekarską (PBL), która tworzona jest w Dziale Bibliografii Medycznych Głównej Biblioteki Lekarskiej im. Stanisława Konopki w Warszawie. PBL rejestruje polską literaturę naukową, kliniczną i fachową z dziedziny medycyny i nauk pokrewnych, organizacji ochrony zdrowia, a także literaturę popularną z zakresu oświaty zdrowotnej. Korzystanie z PBL wymaga subskrypcji [13]. W analizie uwzględniliśmy ponadto punktację czasopism według wskaźnika Index Copernicus [14] stanowiącego alternatywę IF dla wydawców, którym nie powiodło się przy staraniach o umieszczenie swojego czasopisma w Web of Knowledge, a także punktację według listy Ministerstwa Nauki i Szkolnictwa Wyższego [15], która w polskich instytucjach naukowych i uczelniach jest stosowana jako uzupełnienie wskaźnika Impact Factor przy parametrycznej ocenie dorobku naukowego pracowników. Ponadto sprawdziliśmy dostępność zidentyfikowanych czasopism naukowych dla środowiska naukowego, a w szczególności możliwość korzystania z ich zasobów za pośrednictwem Internetu.

\section{Wyniki}

Za pomocą wyżej opisanej metodyki zidentyfikowaliśmy 23 aktualnie ukazujące się w Polsce czasopisma z dziedziny medycyny estetycznej i kosmetologii (tabela 4). Spośród nich, zaledwie cztery mogły być uznane za czasopisma naukowe na podstawie kryteriów podanych w tabeli 2. Były to w kolejności alfabetycznej
Academy of Aesthetic and Anti-Aging Medicine, Dermatologia Estetyczna, Dermatologia i Kosmetologia Praktyczna oraz Polish Journal of Cosmetology (tabela 5). W czasie wykonywania analiz wszystkie cztery czasopisma były indeksowane w Polskiej Bibliografii Lekarskiej, dwa z nich miały punktację Ministerstwa Nauki i Szkolnictwa Wyższego (MNiSW). Żadne z nich nie udostępniało pełnych artykułów w wersji elektronicznej. Jak wykazały przeprowadzone analizy, żadne polskie czasopismo z dziedziny medycyny estetycznej i kosmetologii nie było indeksowane $\mathrm{w}$ prestiżowych międzynarodowych bazach bibliograficznych PubMed, Scopus, EMBASE, Google Scholar czy też ISI Web of Knowledge.

\section{Dyskusja}

W międzynarodowym piśmiennictwie zidentyfikowaliśmy 13 czasopism naukowych poświęconych tematyce medycyny estetycznej i kosmetologii, które są indeksowane w przynajmniej jednym wiodącym wtórnym źródle informacji naukowej. Pięć spośród nich jest indeksowane w najbardziej prestiżowej bazie ISI Web of Knowledge (WOK), w której czasopismom nadaje się Impact Factor (IF) - syntetyczny wskaźnik odzwierciedlający wpływ czasopisma na naukę światową, wykorzystywany również przy ocenie wartości dorobku naukowców i pozycji instytucji naukowych. Wartość IF dla czasopism z dziedziny medycyny estetycznej i kosmetologii w zakresie 0,215-1,849 sugeruje, że wpływ publikacji $\mathrm{z}$ tych dziedzin na naukę jako całość nie jest zbyt wielki. Ilustruje to zestawienie z najwyżej notowanym czasopismem naukowym ( $C A$ : A Cancer Journal for Clinicians, IF=94,262), najwyżej notowanym czasopismem ogólnomedycznym (New England Journal of Medicine, IF=53,484), farmaceutycznym (Nature Reviews Drug Discovery, IF=28,712) czy dermatologicznym (Journal of Investigative Dermatology, IF=6,270) [10]. W grupie 121 polskich czasopism indeksowanych przez WOK najwyżej notowane są Acta Astronomica ( $\mathrm{IF}=3,491)$, zaś wśród polskich czasopism medycznych prym wiodą Pharmacological Reports $(\mathrm{IF}=2,500)$. Znalezienie się na liście czasopism posiadających IF jest uznawane za potwierdzenie najwyższego poziomu naukowego i swoistą nobilitację dla danego tytułu, jednak starania wielu wydawców o uzyskanie IF dla swojego czasopisma kończą się niepowodzeniem. W odpowiedzi na ten problem pojawił się łatwiejszy do uzyskania, alternatywny wskaźnik wartości merytorycznej Index Copernicus (IC), który uwzględniliśmy w przedstawionej analizie polskich czasopism. Żadne międzynarodowe czasopismo z dziedziny medycyny estetycznej i kosmetologii nie posiada wskaźnika IC, natomiast żadne polskie czasopismo z tej dziedziny nie posiada wskaźnika IF. 
Tabela 4. Aktualnie ukazujące się polskojęzyczne czasopisma z dziedziny medycyny estetycznej i kosmetologii, które spełniały założone kryteria wyszukiwania i zostały włączone do prezentowanych badań

\begin{tabular}{|c|c|c|}
\hline Tytul & ISSN & Najnowszy numer \\
\hline Academy of Aesthetic and Anti-Aging Medicine & 2081-3678 & $1 / 2011$ \\
\hline Beauty Forum: Polska : fachowe czasopismo kosmetyczne & $1427-1508$ & $12 / 2010$ \\
\hline Cabines Polska: świat kosmetyki profesjonalnej: nowości, aktualności, wydarzenia & $1897-1032$ & 43/2010-2011 \\
\hline Cosmetic Dentistry: Beauty \& Science & $1733-5418$ & $3 / 2010$ \\
\hline Cosmetic reporter & $1895-6939$ & $4 / 2010$ \\
\hline Cosmetology Today & $1895-5592$ & $4 / 2010$ \\
\hline Dermatologia Estetyczna: specjalistyczny magazyn medyczny & $1507-661 X$ & $6 / 2010$ \\
\hline Dermatologia i Kosmetologia Praktyczna: kwartalnik dla dermatologów, lekarzy medycyny estetycznej i kosmetologów & $1895-9717$ & $4 / 2010$ \\
\hline Estetica polska: fryzjerstwo, trendy, style & $1897-0303$ & $2 / 2011$ \\
\hline Gabi.net: Estetyka \& Zdrowie & $1733-6090$ & $4 / 2010$ \\
\hline Kosmetologia: Zeszyty Naukowe Wyższej Szkoły Nauk Społecznych z siedzibą w Lublinie & 2082-7105 & $1 / 2010$ \\
\hline Kosmetyka i Kosmetologia & $1231-4153$ & $1-2 / 2011$ \\
\hline Kosmetyki: magazyn specjalistów urody i zdrowia & $1234-4575$ & $1-2 / 2011$ \\
\hline Kosmetyka profesjonalna & $1734-7440$ & $4 / 2010$ \\
\hline Les Nouvelles Esthetiques \& spa & $1234335-4$ & $5 / 2010$ \\
\hline Medycyna Estetyczna i Anti-Aging & $1897-3132$ & $4 / 2010$ \\
\hline Nowoczesna Medycyna Estetyczna & 2082-2987 & $7-8 / 2010$ \\
\hline Polish Journal of Cosmetology & $1731-0083$ & $4 / 2010$ \\
\hline Postępy Kosmetologii: kwartalnik pod patronatem Niepublicznej Wyższej Szkoły Kosmetycznej we Wrocławiu & 2081-2949 & $1 / 2011$ \\
\hline Project of Beauty: pismo dla profesjonalistów: moda, fryzjerstwo, kosmetyka, paznokcie, wizaż & 2080-3176 & $4 / 2010$ \\
\hline $\begin{array}{l}\text { SOFW Journal: international journal for applied science: personal care, detergents, specialties } \\
\text { Polskie Towarzystwo Kosmetologów }\end{array}$ & $1506-7181$ & $4 / 2010$ \\
\hline Stomatologia Estetyczna & $2083-4055$ & $1 / 2011$ \\
\hline Wiadomości Kosmetyczne & 1895-3948 & $2 / 2011$ \\
\hline
\end{tabular}

Tabela 5. Przegląd aktualnie ukazujących się polskich indeksowanych czasopism naukowych z dziedziny medycyny estetycznej i kosmetologii

\begin{tabular}{|c|c|c|c|c|c|c|c|c|c|}
\hline Tytul & Podtytul & ISSN & Częstottiwoóć & Wychodzi od & Zakres analizy & $\begin{array}{l}\text { Artykuly } \\
\text { oryginalne }\end{array}$ & IC (2010) & PBL & MNiSW \\
\hline $\begin{array}{l}\text { Academy of Aesthetic } \\
\text { and Anti-Aging } \\
\text { Medicine }\end{array}$ & $\begin{array}{l}\text { Oficjalne czasopismo Polskiego Towarzystwa } \\
\text { Medycyny Estetycznej i Anti-Aging, Oddział } \\
\text { Polskiego Towarzystwa Lekarskiego }\end{array}$ & $2081-3678$ & kwartalnik & 2007 & $3 / 2010-2 / 2011$ & 2 [16-17] & 2.38 & + & - \\
\hline Dermatologia Estetyczna & Specjalistyczny magazyn medyczny & $1507-661 X$ & dwumiesięcznik & 1999 & $1 / 2010-6 / 2010$ & $10[18-27]$ & 3.41 & + & $6 \mathrm{pkt}$ \\
\hline $\begin{array}{l}\text { Dermatologia } \\
\text { i Kosmetologia } \\
\text { Praktyczna }\end{array}$ & $\begin{array}{l}\text { Kwartalnik dla dermatologów, lekarzy } \\
\text { medycyny estetycznej i kosmetologów }\end{array}$ & 1895-9717 & kwartalnik & 2006 & $1 / 2010-4 / 2010$ & $1[28]$ & 1.95 & + & - \\
\hline $\begin{array}{l}\text { Polish Journal } \\
\text { of Cosmetology }\end{array}$ & - & 1731-0083 & kwartalnik & $2003^{*}$ & $1 / 2010-4 / 2010$ & 18 [29-46] & - & + & $6 \mathrm{pkt}$ \\
\hline
\end{tabular}

Należy podkreślić, że spośród czterech wytypowanych polskich czasopism naukowych z dziedziny medycyny estetycznej i kosmetologii, żadne nie spełniało wszystkich cech czasopisma naukowego. Najlepiej wypadło czasopismo Polish Journal of Cosmetology, którego układ odpowiada klasycznej formie czasopisma naukowego, spis treści wyróżnia artykuły oryginalne i przeglądowe, reklamy są wyraźnie oddzielone od artykułów naukowych. Czasopismo to publikuje najwięcej oryginalnych artykułów badawczych i cechuje się największą interdyscyplinarnością (m. in. posiada dział medyczny, wydawane jest pod patronatem Polskiego Towarzystwa Farmaceutycznego). Zasięg tego czasopisma jako platformy wymiany informacji naukowej ogranicza jednak jego mała dostępność wynikająca z braku pełnych tekstów prac w Internecie oraz dość długiego oczekiwania na realizację zakupu wersji drukowanej. $\mathrm{Z}$ punktu widzenia autorów chcących publikować $\mathrm{w}$ tym czasopiśmie, istotnym problemem jest utrudniona komunikacja z redakcją, długi czas oczekiwania na decyzję redakcyjną i publikację artykułu (znane są przypadki rocznego oczekiwania autorów na jakąkolwiek odpowiedź redakcji w sprawie złożonej pracy), a także opóźnienia wydawnicze (we wrześniu 2011 roku nie ukazał się jeszcze nr 1/2011 tego kwartalnika). Dermatologia Estetyczna jest periodykiem łączącym formę magazynu 
branżowego (taką funkcję określa jego podtytuł) publikującego wywiady, reportaże, artykuły sponsorowane i reklamy, z publikowaniem artykułów oryginalnych i przeglądowych, przy czym treści naukowe nie są wyraźnie oddzielone od tekstów „magazynowych”. Formą magazynu cechuje się również czasopismo Academy of Aesthetic and Anti-Aging Medicine, o czym świadczy przewaga tekstów o charakterze magazynowym (wywiady, artykuły sponsorowane, reklamy), typowa dla czasopism popularnych organizacja treści (brak podziału na tomy, brak ciągłości numeracji stron w kolejnych zeszytach), a w szczególności znikoma liczba artykułów oryginalnych (w ostatnich 4 numerach tego kwartalnika opublikowano łącznie 2 artykuły oryginalne). Dermatologia $i$ Kosmetologia Praktyczna również ma format magazynowy, dominują tłumaczenia artykułów z czasopism zagranicznych, a $\mathrm{w}$ ciągu ostatniego roku czasopismo opublikowało zaledwie jeden oryginalny artykuł naukowy przy którym nie podano informacji, że jest przedrukiem [28].

W polskim środowisku naukowym toczy się dyskusja, czy polskojęzyczne czasopisma naukowe mają w ogóle rację bytu. Zdania w tej materii są bardzo podzielone, sięgając od radykalnej tezy, że wszystkie publikacje polskich badaczy powinny być publikowane w języku państwowym, aż po przeciwny pogląd głoszący, że w nauce liczą się tylko prace publikowane w językach kongresowych w czasopismach o międzynarodowym zasięgu. Postępująca globalizacja i polityka integracji polskiej nauki z nauką światową wydaje się przemawiać na korzyść tej drugiej opcji, a kariera akademicka w naukach biomedycznych oparta wyłącznie na publikacjach polskojęzycznych wydaje się obecnie niemożliwa. Jednak dopóki istnieje akademickie nauczanie medycyny i kosmetologii w języku polskim, dopóty niezbędna będzie wymiana w tym języku doświadczeń, idei oraz wyników badań oryginalnych, gdyż tylko w taki sposób można zapewnić aktualność i żywotność polskiego słownictwa fachowego w tych dziedzinach. Zatem na obecnym etapie środowisko polskich naukowców aktywnych w dziedzinie medycyny estetycznej i kosmetologii potrzebuje polskojęzycznych czasopism naukowych publikujących nie tylko dobre artykuły przeglądowe, ale przede wszystkim rzetelne i odkrywcze oryginalne artykuły badawcze.

Zarówno kształcenie podyplomowe w zakresie medycyny estetycznej, jak i kształcenie na poziomie studiów wyższych w zakresie kosmetologii ma w naszym kraju stosunkowo krótką tradycję i odbywa się głównie w szkołach niepublicznych $\mathrm{z}$ ograniczonym potencjałem naukowym. Nie prowadząca własnych badań naukowych kadra dydaktyczna takich placówek często nie widzi potrzeby wyrobienia u studentów nawyku sięgania po pierwotne źródła informacji naukowej. W takiej sytuacji studenci poprzestają na korzystaniu ze źródeł internetowych o niskiej wiarygodności lub podręczników, które jako opracowania wtórne siłą rzeczy podają informacje z kilkuletnim opóźnieniem w stosunku do aktualnego stanu wiedzy. Poprawę tej sytuacji można osiągnąć przez zapewnienie wszystkim zainteresowanym nieograniczonego dostępu do aktualnych czasopism naukowych z zakresu medycyny estetycznej i kosmetologii. Obecnie głównymi barierami w korzystaniu $\mathrm{z}$ polskich czasopism naukowych są ograniczenia finansowe (koszt prenumeraty czasopism) oraz ograniczenia fizyczne i czasowe (konieczność wyprawy do biblioteki prenumerującej dany tytuł, godziny otwarcia, czas dojazdu, itd.). W tym kontekście idealnym rozwiązaniem wydaje się stworzenie czasopisma naukowego dostępnego bez ograniczeń w Internecie, jednak żadne $\mathrm{z}$ aktualnie wydawanych polskojęzycznych czasopism naukowych poświęconych medycynie estetycznej i kosmetologii nie udostępnia artykułów w formie elektronicznej. Publikowanie czasopism naukowych w Internecie ma długą tradycję [47,48], a idea czasopism udostępnianych bezpłatnie (Open Access) zyskuje coraz większe poparcie polityczne jako ważny środek upowszechniania osiągnięć nauki, zwiększania potencjału naukowego i społecznego, a także wyrównywania szans między ubogimi i bogatymi [49,50]. Zdaniem ekspertów liczba czasopism naukowych w formule Open Access będzie się zwiększać [51]. Biorąc pod uwagę, że studenci (a nierzadko także bardziej zamożni lekarze) nie są zbyt skłonni płacić za dostęp do literatury naukowej, a znajomość języków obcych wśród Polaków nadal nie jest powszechna, stworzenie polskojęzycznego czasopisma naukowego typu Open Access poświęconego tematyce estetologii medycznej i kosmetologii będzie istotnym bodźcem dla rozwoju tych dziedzin w naszym kraju. Badania naukowe potwierdzają ponadto, że pojawienie się czasopism naukowych typu Open Access wydatnie zwiększa korzystanie z literatury naukowej przez „pasywnych konsumentów” informacji naukowej [52], zatem pojawienie się takiego czasopisma będzie również stymulować samodzielne doskonalenie zawodowe lekarzy oraz kosmetologów działających poza ośrodkami akademickimi. Autorzy publikujący swoje artykuły oryginalne i przeglądowe w czasopiśmie naukowym typu Open Access zyskają znacznie większą rzeszę czytelników, przez co zwiększy się ich faktyczny wpływ na rzeczywistość naukową i praktykę zawodową, a także rozpoznawalność i uznanie środowiska.

\section{Wnioski}

Obecność polskojęzycznych czasopism naukowych dedykowanych medycynie estetycznej i kosmetologii publikujących oryginalne prace badawcze stwarza podstawę dla rozwoju tych dyscyplin w ramach nauki polskiej. Zasięg tych czasopism jest jednak ograniczony 
do subskrybentów, żadne z nich nie udostępnia pełnych artykułów przez Internet. Daje się odczuć brak ogólnodostępnego czasopisma interdyscyplinarnego, umożliwiającego swobodną komunikację między przedstawicielami różnych środowisk zawodowych aktywnych w obszarze medycyny estetycznej i kosmetologii. W odpowiedzi na to zapotrzebowanie proponujemy powołanie nowego czasopisma Estetologia Medyczna i Kosmetologia - czasopisma typu Open Access dedykowanego komunikacji między polskimi lekarzami, kosmetologami, farmaceutami oraz przedstawicielami innych specjalności aktywnymi w zakresie medycyny estetycznej i kosmetologii.

\section{Piśmiennictwo}

1. Day RA: How to write and publish a scientific paper. Cambridge University Press, Cambridge 1995: 9.

2. US National Library of Medicine, National Institutes of Health: PubMed. URL: http://www.ncbi.nlm.nih. gov/pubmed/ (dokument elektroniczny, stan na dzień 8.08.2011).

3. Elsevier: EMBASE. URL: http://embase.com/home (dokument elektroniczny, stan na dzień 8.08.2011).

4. Elsevier: Scopus. URL: http://www.scopus.com/home. url (dokument elektroniczny, stan na dzień 8.08.2011).

5. Thomson Reuters: Web of Knowledge. URL: http://apps. webofknowledge.com/ (dokument elektroniczny, stan na dzień 8.08.2011).

6. Google: Google Scholar. URL: http://scholar.google.pl/ (dokument elektroniczny, stan na dzień 8.08.2011).

7. Falagas ME, Pitsouni EI, Malietzis GA, Pappas G: Comparison of PubMed, Scopus, Web of Science, and Google Scholar: strengths and weaknesses. FASEB J 2008; 22(2): 338-42.

8. Kulkarni AV, Aziz B, Shams I, Busse JW: Comparisons of citations in Web of Science, Scopus, and Google Scholar for articles published in general medical journals. JAMA 2009;302(10):1092-6.

9. Bakkalbasi N, Bauer K, Glover J, Wang L: Three options for citation tracking: Google Scholar, Scopus and Web of Science. Biomed Digit Libr 2006;3:7.

10. Thomson Reuters: ISI Web of Knowledge Journal Citation Reports. URL: http:/admin-apps. webofknowledge.com/JCR/JCR?RQ=HOME (dokument elektroniczny, stan na dzień 8.08.2011).

11. Biblioteka Narodowa: Katalogi. URL: http://alpha.bn.org. pl/ (dokument elektroniczny, stan na dzień 8.08.2011).

12. Ośrodek Koordynacji Centrum NUKAT Biblioteki Uniwersyteckiej w Warszawie: Narodowy Uniwersalny Katalog Centralny NUKAT. URL: http://www.nukat.edu. pl/ (dokument elektroniczny, stan na dzień 8.08.2011).

13. Główna Biblioteka Lekarska im. Stanisława Konopki w Warszawie: Polska Bibliografia Lekarska 1991-2011. URL: $\quad$ http://gbl.home.pl/cgi-bin/gblbase.pl/pblb09 (dokument elektroniczny, stan na dzień 8.08.2011).

14. Index Copernicus International: Index Copernicus Journals Master List. URL: http:/journals. indexcopernicus.com/ (dokument elektroniczny, stan na dzień 8.08.2011).

15. Ministerstwo Nauki i Szkolnictwa Wyższego: Wykaz wybranych czasopism wraz z liczbą punktów za umieszczoną w nich publikację naukową. URL:http://www.nauka.gov.pl/fileadmin/ user_upload/Finansowanie/finansowanie_nauki/ Lista_czasopism/20100827_UJEDNOLICONY WYKAZ_ZA_2007_-2010_11_06_2010.pd $\bar{f}$ (dokument elektroniczny, stan na dzień 6.11 .2010 ).

16. Janecka J: Zależność pomiędzy zamiarem poddania się zabiegom medycyny estetycznej a depresją. Acad Aesthet Anti-Aging Med 2011; (1): 55-63.

17. Surowiak P: Mezoterapia versus osocze bogatopłytkowe. Acad Aesthet Anti-Aging Med 2011; (2): 7-10.

18. Magdziarz-Orlitz J: Metody leczenia zachowawczego wrastającego paznokcia - doświadczenia własne. Dermatol Estet 2010;12(1):19-26.

19. Harupa M, Bury M, Reich A: Ocena wiedzy na temat wpływu promieniowania UV na skórę wśród populacji polskiej - badanie ankietowe. Dermatol Estet 2010;12(1):44-50.

20. Kmieć ML, Prusińska-Bratoś M, BroniarczykDyła G: Ocena skuteczności działania zabiegów mikrodermabrazji w usuwaniu zmian chorobowych i defektów kosmetycznych. Dermatol Estet 2010;12(2):109-16.

21. Deda A, Adamczyk J, Wilczyński S: Ocena właściwości optycznych wybranych preparatów promieniochronnych, dostępnych na polskim rynku aptecznym. Dermatol Estet 2010;12(3):170-6.

22. Maciejewska J, Placek W: Profilaktyka czerniaka. Dermatol Estet 2010;12(3):187-90.

23. Macierzyńska A, Pierzchała E: Wpływ fal elektromagnetycznych o wysokiej częstotliwości (RF) na poprawę elastyczności skóry. Dermatol Estet 2010;12(5):291-9.

24. Adamski Z, Kursa-Orłowska J, Neneman-Hirsch A, Orłowski M: Dobry efekt terapeutyczny maści zawierającej witaminę B12 u chorych na łuszczycę pospolitą oraz chorych na atopowe zapalenie skóry. Dermatol Estet 2010;12(5):301-8.

25. Bazela K, Dębowska R, Tyszczuk B, Dźwigałowska A, Rogiewicz K, Eris I: Dermokosmetyki do pielęgnacji skóry z przebarwieniami - ocena skuteczności działania. Dermatol Estet 2010;12(5):320-5.

26. Woźniak M, Zegarska B, Czajkowski R, Grupka M, Fatz-Grupka A, Kaczmarek-Skamira E: Wpływ alfa hydroksykwasów na poziom nawilżenia skóry - badania własne. Dermatol Estet 2010;12(5):328-32.

27. Deda A, Wilczyński S, Pierzchała E, Pilawa B: Ocena właściwości natłuszczających i nawilżających preparatów do pielęgnacji rąk. Dermatol Estet 2010;12(6):375-80.

28. Capitanio B, Napolitano M, Berardesca E, Ricardo M: Badanie kliniczne oceniające skuteczność produktu przeciwtrądzikowego Aknicare. Dermatol Kosmetol Prakt 2010;5(1):13-9.

29. Wilczyński S, Zdybel M, Deda A, Pierzchała E: Właściwości antyoksydacyjne suplementów diety stosowanych $\mathrm{w}$ kosmetologii. Pol J Cosmetol 2010;13(1):48-53.

30. Hromvyk B, Tereshtshuk S, Vermenitsheva I, Zaprutko T, Zaprutko L: Kryteria wyboru past do zębów przez studentów w Polsce i na Ukrainie. Pol J Cosmetol 2010;13(1):54-64. 
31. Linka W.A: Technologia otrzymywania tabletek o modyfikowanym profilu uwalniania zawierających suche wyciągi roślinne (o działaniu afrodyzjakalnym), aminokwasy oraz witaminy. Pol J Cosmetol 2010;13(1):65-72.

32. Bujak T, Zgoda MM, Bodek KH: Kremy aloesowe do rąk. Pol J Cosmetol 2010;13(2):92-8.

33. Dana A, Gadecka P, Glinka R: Świadomość i wiedza pracowników gabinetów solaryjnych na temat profilaktyki czerniaka. Pol J Cosmetol 2010;13(2):99-105

34. Sułek M.W, Zięba M: Wpływ pochodnych silikonów o wysokim stopniu etoksylowania na właściwości użytkowe szamponów. Pol J Cosmetol 2010;13(2):106-18

35. Samczewska G: Wpływ olejowego wyciągu z nagietka na parametry reologiczne i dostępność farmaceutyczną chlowodorku morfiny $\mathrm{z}$ modelowanych maści. Pol J Cosmetol 2010;13(2):119-28.

36. Piechota-Urbańska M, Urbański W, Kołodziejska J, Samczewska G, Berner-Strzelczyk A: Ocena wpływu zastosowanego podłoża na proces uwalniania składowych wyciągu z mącznicy lekarskiej z półstałych preparatów podawanych na skórę o działaniu wybielającym. Pol J Cosmetol 2010;13(2):129-38.

37. Wilczyński $\mathrm{S}$, Wiewióra $\mathrm{M}$, Deda $\mathrm{A}$, Zdybel $\mathrm{M}$ : Porównanie właściwości antyoksydacyjnych metoda EPR wybranych olei roślinnych stosowanych w kosmetologii. Pol J Cosmetol 2010;13(2):139-46.

38. Zarębska A, Antoszewski B: Powikłania skórne związane $\mathrm{z}$ korzystaniem $\mathrm{z}$ solarium i motywacja do „sztucznego opalania”. Pol J Cosmetol 2010;13(3):166-70.

39. Antoszewski B, Kasielska A, Jokiel I, Fijałkowska M: Zmiany skórne - prewencyjna rola kosmetologa. Pol J Cosmetol 2010;13(3):171-6.

40. Burda K, Walędziak M, Kszysztof K, Nowakowska E, Ratajczak P, Gandecka A, Michalak M: Ocena skuteczności witaminy A i jej pochodnych w pielęgnacji skóry. Pol J Cosmetol 2010;13(3):177-95.

41. Chłopicka J, Gonciarz A: Aktywność antyoksydacyjna i zawartość polifenole w kakao i kilku rodzajach czekolad zaleceniem do wykorzystania w kosmetologii. Pol J Cosmetol 2010;13(3):196-202.

42. Samczewska G: Wpływ rocznego przechowywania na parametry reologiczne i dostępność farmaceutyczną chlowodorku morfiny $\mathrm{z}$ modelowych maści $\mathrm{z}$ wyciągiem $\mathrm{z}$ nagietka lekarskiego. Pol J Cosmetol 2010;13(3):203-13.

43. Antoszewski B, Fijałkowska M, Zarębska A, Kasielska A: Rozstępy ciążowe - czynniki ryzyka i metody zapobiegania. Pol J Cosmetol 2010;13(4):235-41.

44. Krzysztoszek J, Matecka M: Profil wymagań kompetencyjnych w zawodzie kosmetologa. Pol J Cosmetol 2010;13(4):242-57.

45. Borowiecka J, Wesołowski W, Kozłowska-Lewecka M: Analiza wyrobów perfumeryjnych typu szypr techniką GC/MS. Pol J Cosmetol 2010;13(4):258-69.

46. Chrząstek L, Dondela B: Makro- i mikroelementy w kosmetyce. Pol J Cosmetol 2010;13(4):270-9.

47. Śpiewak R, Kasztelowicz P, Staniak G: Publikowanie W Internecie. W: Lekarski Internet, red. Szymaś J, Śpiewak R. Ad Punctum, Lublin 1995: 71-7.
48. Śpiewak R: Zmierzch ery Gutenberga w świecie infostrad. Czy grozi nam upadek tradycyjnych czasopism biomedycznych? Gazeta Lekarska 1996;(5):72-3.

49. Fraser SG: Open Access - the future of medical publishing. Clin Ophthalmol 2007;1(3):199-200.

50. Watson R: EC to promote open access publishing. BMJ 2007;334(7590):389.

51. O'Dowd A: Open access approach to medical research publishing will continue to grow, experts predict. BMJ 2011;342:d3307.

52. Davis PM: Open access, readership, citations: a randomized controlled trial of scientific journal publishing. FASEB J 2011;25(7):2129-34.

\section{Finansowanie i konflikt interesów}

Przedstawione badania $i$ przygotowanie niniejszej publikacji zostało $\mathrm{w}$ całości sfinansowane $\mathrm{z}$ własnych środków autorów. RS jest wydawcą nowego interdyscyplinarnego czasopisma z zakresu estetologii medycznej i kosmetologii, a przedstawiona praca była elementem analizy zapotrzebowania na nowe czasopismo naukowe w tym zakresie. AZ deklaruje niewystępowanie konfliktu interesów w odniesieniu do treści zawartych w niniejszej pracy.

\section{Adres do korespondencji}

prof. UJ dr hab. med. Radosław Śpiewak Zakład Dermatologii Doświadczalnej i Kosmetologii

Wydział Farmaceutyczny UJ

ul. Medyczna 9, 30-688 Kraków

Tel.: 1262058 30, Fax: 126205645

E-mail: spiewak.eu@gmail.com

Data złożenia: 23.08.2011

Data akceptacji: 19.09.2011

Data aktualizacji: 30.11.2011 